\title{
Indonesian Journal of Teaching in Science
}

\section{Game-based Activity Method: A Case of Grade 5 Students}

H. Hanna, Sofia L. Abdul*, Angel Dianne B. Dela Cruz, Zyji T. Manalo, Fiona Marie L. Papna, Jayson A. Falle

Sultan Kudarat State University, the Philippines

Correspondence: E-mail: hannasofiaabdul@sksu.edu.ph

\section{A B S T R A C T S}

The main purpose of this research is to further address this gap with pupils to understand further game-based learning. The study was conducted at Tacurong City, Sultan Kudarat. Five students (grade 5) of Tacurong Pilot Elementary School were selected purposively and considered their availability. The researchers used semi-structured questionnaires via an online one-on-one interview with the participants through Google Meet. This was to find out that the game-based activity method makes them more interested in learning and it becomes easier for them generally to answer their homework and activities using the game-based method. It is disclosed that the use of games to show educational content inevitably raises the question of their compatibility with deep learning. Despite their disadvantages, games have a series of undeniable positive features: using one and also the same game to develop several skills in students at once; providing visual, life-like examples for practical situations; forcing all learners to undertake learning, discovery, thinking, thus enhancing self-esteem and self-improvement.

\begin{tabular}{l}
\hline A R T I C L E I N F O \\
\hline Article History: \\
Submitted/Received 17 Jan 2021 \\
First revised 16 Feb 2021 \\
Accepted 24 Feb 2021 \\
First available online 26 Feb 2021 \\
Publication date 01 Mar 2021 \\
\hline Keyword: \\
Activity, \\
Experience, \\
Game, \\
Game-based learning, \\
Pupils, \\
Teaching method.
\end{tabular}

ARTICLE INFO

First revised 16 Feb 2021

Accepted 24 Feb 2021

2021

Keyword:

Activity

Game-based learning

Teaching method. 


\section{INTRODUCTION}

The growing popularity of digital games has led to their widespread use and application. Digital games are often used in education, in the form of serious games that concentrate more on primary purposes (Anastasiadis et al., 2018).

As with any new educational approach, there are numerous challenges to using games both in the classroom and in library instruction. Spiegelman and Glass (2008) discuss potential barriers to game-based learning. These include the following: games take time to learn and design properly, involve materials that range from the inexpensive to the costly, design efforts are often funded via grants which have to be managed, pedagogical and technical supports might be necessary (additional resources), issues of access and the digital divide, and an examination is needed as to whether students prefer this approach to teaching. Additionally, the benefits of game-based learning, including increased engagement and motivation, greater learning, are too compelling to ignore (Spiegelman \& Glass, 2008).

This study aimed to describe elementary students' experiences of using the game-based method in their activities. This provided insight into how a game-based method can be successfully deployed and their possible impacts, in addition to the interdisciplinary study of game and learning mechanics. We would like to address this gap with elementary students further to understand game-based methods further. This study showed a case in grade 5 elementary students' experiences on using the game-based activity method in answering their activities.

\section{METHODS}

We used a qualitative design specifically the case study. Exploratory type is the type of case study that was used in this study with five students (grade 5) from Tacurong Pilot Elementary School, the Philipines, was purposively chosen. Exploratory studies are trying to find an answer to such questions, like 'who' or 'what'. They include experiments, questionnaires, and interviews, and so on. The participants of the study must come from the grade 5 pupils of Tacurong Pilot Elementary School; pupils who enrolled in an online class; and pupils who have experience in using game-based learning as a method in answering their activities. The researchers used semi-structured questions to gather the data. The study had been conducted in an online interview via Google Meet due to COVID-19 restrictions. Exploratory-Narrative Analysis was used on data analysis.

\section{RESULTS AND DISCUSSION}

In this study, the researchers gathered the experiences of 5 students using a game-based activity method by conducting interviews with 5 participants from grade 5 pupils of Tacurong Pilot Elementary School. The interviewers made the participants describe their experiences of using the game-based activity method.

Game-based activities are motivating and highly engaging for students and can be an effective way for students to learn when embedded in a curriculum. In addition, Anastasiadis et al. (2018) quoted that game-based learning involves more than just creating games for kids to play, but also constructing engaging learning activities that may gradually impart concepts and direct students toward an ultimate goal. Based on their answers, the participants described it easily and straight to the point. All of them stated how the game-based activity method is easy and fun to use. 
As students build games, they have the opportunity to engage in genuine group ventures that improve their problem-solving, communication, and teamwork skills. For the pupils, saying that their teacher guides them and only gives links and instructions for their activities means that they can answer the questions at their own pace. Moreover, learners are also encouraged to notice and comprehend reflective thinking and thought initiatives. They have the potential to be creative thinkers (Sangsawang, 2020).

The other participants stated their difficulties due to some reasons they said. Most had difficulties due to technical problems in accessing the links that were provided by their teachers that were caused by the slow or lack of internet connection in their area. And the other one is unable to answer the questions. However, considering the circumstances, the overall impression still helps students to work remotely with their lecturers and peers to share and reflect on their knowledge.

One of how learning tries to motivate pupils is through this game-based activity is to arouse excitement and instill confidence. According to the responses of the participants, they had fun, enjoyment, and a tint of satisfaction to the game activities they participated in. Also, it made them hyper and participative in the tasks which promptly deviated them from getting bored in their online classes. Concurrently, it appears that their attention and motivation are improved, which aids their learning process (Anastasiadis et al., 2018).

Aside from the entertainment brought by the games, competition is also inevitable for students which brings pressure and stress. Some of them said they were worried and nervous because they might have difficulty with other questions in the game. After all, the other questions were not yet taught to them, while one of them was concerned with their leaderboard. Thus, the participants were under pressure. Other participants were not pressured because they preferred to enjoy and remain calm playing and answer games. Children will discover and learn many more facts and lessons as they grow up. Furthermore, will help them organize things into different shapes and reason logically about concrete events (Putri et al., 2018).

Hearing their answers that the game-based activity method makes them more interested in learning is incredibly good news to hear and know because it can be seen that they want to use this method of learning. This also implies that it becomes easier for them generally to answer their homework and activities using the game-based method.

\section{CONCLUSION}

The use of games to show educational content inevitably raises the question of their compatibility with deep learning. The participants displayed positive attitudes toward the use of game-based as a learning method and felt that the approach contributed to learning. The majority of pupils accepted this learning method and hoped to continue using this approach in the future. The pupils also expressed that learning with the game-based method could assist them to gain knowledge in a fun way and that the game-based learning method increased their interest in modes of answering at their own pace creatively. The pupils also said that it was easy to use. It was an easy task for them to answer their activities. Both the experience and the achievement show that the digital game within a gamified learning experience was very effective and enjoyable. Moreover, the use of the game-based method to promote learning also enhanced learning motivation and learning effectiveness. This result shows that the game-based learning framework increases pupils' learning achievement. The 
introduction of a game-based learning method to a classroom environment is both feasible and useful for long-term learning.

\section{ACKNOWLEDGMENT}

We thank our Research Advisers, Panel of Examiners, Participants of the Study, The Institution - Sultan Kudarat State University - Laboratory Science High School, the Researchers' Families, and above all.

\section{AUTHORS' NOTE}

The authors declare that there is no conflict of interest regarding the publication of this article. Authors confirmed that the paper was free of plagiarism.

\section{REFERENCES}

Anastasiadis, T., Lampropoulos, G., and Siakas, K. (2018). Digital game-based learning and serious games in education. International Journal of Advances in Scientific Research and Engineering, 4(12), 139 -144.

Putri, H. E., Misnarti, M., and Saptini, R. D. (2018). Influence of concrete-pictorial-abstract (cpa) approach towards the enhancement of mathematical connection ability of elementary school students. EduHumaniora: Jurnal Pendidikan Dasar Kampus Cibiru, 10(2), 61-71.

Sangsawang, T. (2020). An instructional design for online learning in vocational education according to a self-regulated learning framework for problem solving during the covid-19 crisis. Indonesian Journal of Science and Technology, 5(2), 283-298.

Spiegelman, M., and Glass, R. (2017). Gaming and learning: Winning information literacy collaboration. College and Research Libraries News, 69(9), 522-547. 